\title{
A BRAVURA INDÔMITA DA JUSTIÇA PENAL: O IMAGINÁRIO PUNITIVO À LUZ DA ÉTICA DA VINGANÇA
}

\author{
Thiago Fabres de Carvalho*
}

"Os ímpios fogem sem ninguém a persegui-los" (Provérbios 28:1)

\section{RESUMO}

O presente texto pretende debater as fontes imaginárias da Justiça Penal articulada pela filosofia ética da vingança. Com base no enredo da obra cinematográfica Bravura Indômita, sobretudo das significações projetadas pela personagem Mattie Ross, no espectro de seu horizonte existencial e histórico, o texto busca perceber as relações existentes entre pena e vingança, a fim de traçar algumas linhas divisórias que permitem antever os marcos principais que diferenciam a vingança destruidora e mortífera e as dimensões de um imaginário punitivo situado nas representações simbólicas de uma ética da vingança.

Palavras-chave: Vingança. Justiça penal. Pena.

* Doutor em Direito pela Unisinos; professor de Filosofia do Direito, Direito Penal e Processo Penal da FDV; advogado. 


\section{ABSTRACT}

This text wants to debate the imaginary sources of criminal justice articulated by the ethical philosophy of revenge. Based on the plot of the novel film "The True Grit", especially the meanings projected by the character Mattie Ross, within its historical and existential horizon, this text it seeks to understand the relationship between punishment and revenge, with the purpose to draw some boundary lines that allow to foresee the major milestones that differentiate destructive and deadly revenge and dimensions of an imaginary punishment situated in the symbolic representations of an "ethic of revenge".

Keywords: Revenge. Criminal justice. Punishment.

\section{INTRODUÇÃO}

Parece certo que “[...] ninguém acreditava que uma menina tão nova pudesse sair de casa durante o inverno para vingar a morte do pai. Mas aconteceu". Mattie Ross nos conta que, "[...] tinha apenas 14 anos de idade quando um covarde chamado Tom Chaney atirou em seu pai, roubando-lhe a vida e o cavalo. E duas peças de ouro da Califórnia que trazia no bolso da calça". ${ }^{1}$

Relembra, então, a hoje senhora Ross, que Chaney era um homem contratado por seu pai, uma espécie de empregado temporário: "Papai o tinha levado até Fort Smith para ajudá-lo a trazer de volta alguns Mustangs que ele tinha comprado. Na cidade, Chaney foi ao saloon para beber. E, jogando cartas, perdeu todo o seu dinheiro. Achou que estava sendo enganado e voltou na pensão para pegar o rifle. Quando papai tentou intervir, Chaney atirou nele. Chaney fugiu. Poderia ter ido a passo lento com seu cavalo, porque ninguém na cidade se incomodou em persegui-lo. Sem dúvida, Chaney imaginava que havia escapado sem punição. Mas estava errado. Deve pagar por tudo neste mundo, de uma forma ou de outra. Nada é de graça, exceto a graça de Deus".

A menina de "gênio forte" só tem um pensamento em sua mente incansável: vingar a morte do pai. Electra reencarnada. Diante do espetáculo público dos enforcamentos, anseia ver o dia em que Chaney será lavado 
ao cadafalso pelo seu crime. Extasiada, indaga ao xerife sobre as buscas, o paradeiro do criminoso e as possibilidades de captura. Ereafirma, com todas as letras, ao representante da lei, da Justiça pública, seu desejo de vingança: "Pretendo ver o assassino do meu pai enforcado". Assim, inquire o xerife sobre a contratação de um U.S. Marshal, um caçador de recompensas, misto de justiceiro e oficial da lei, que se lança à captura de criminosos em nome das autoridades e em troca de compensações monetárias.

O xerife indica o nome de Marshal Rooster Cogborn, homem velho, porém conhecido pela sua valentia, profundamente temido pelos malfeitores procurados, pois era extremamente duro e implacável com seus perseguidos. Mattie Ross insiste na sua contratação. Quer, justamente, contar com o auxílio do mais impiedoso e infalível dos justiceiros: "Me disseram que o senhor é um homem de bravura indômita". A menina Mattie, sempre com sua firmeza de caráter, negocia os termos do acordo. Cem dólares será o custo da empreitada. Deseja ver o criminoso capturado e entregue à Justiça de Fort Smith, local do assassinato de seu pai, a fim de que seja submetido à jurisdição do juiz Parker. E finalmente enforcado.

De outra sorte, o oficial La Boeuf também persegue Chaney pela morte de um senador no Texas. Encontra-se há meses no encalço do criminoso, no desejo de detê-lo e levá-lo àquela jurisdição. Ao deparar-se com Mattie, o oficial afirma sua pretensão de encaminhar o malfeitor à Justiça texana, local em que lhe aguarda uma recompensa bem elevada, uma vez que a morte de um senador constitui um malum em si e não simplesmente um malum prohibita. A menina de imediato responde, com a rispidez e inflexibilidade de seu gênio indomável, do tamanho de sua bravura, também ela indômita: "Quando Chaney for capturado, ele virá para Fort Smith para ser enforcado. Não vou deixar que vá para o Texas para ser enforcado por matar um senador". Eis que La Boeuf argumenta: "Não é importante onde será enforcado, é?". E Mattie contra-ataca sem respirar: "Para mim é! E para você?".

A menina doravante não descansa simplesmente com a contratação do justiceiro. Mesmo diante de todos os inúmeros perigos e dificuldades que a missão contém, segue os oficiais Marshal Cogborn e La Boeuf na expedição, na captura do homem que the abriu a ferida do assassinato de seu querido pai, a despeito da contrariedade incisiva de ambos. Decide viver cada momento, sentir na carne, ver com os próprios olhos, entregar- 
se de corpo e alma ao percurso vindicativo. E segue, definitivamente, ao lado de ambos, montada em seu cavalo "Pretinho".

A partir desse enredo inicial, tecido pela dramaturgia cinematográfica de Bravura Indômita, o presente texto pretende debater não o conceito, mas os sentidos filosófico e ético-político da vingança. Com efeito, no imaginário da Justiça penal, ${ }^{2}$ René Girard ressalta que “[...] não existe nenhum princípio de justiça realmente muito diferente de um princípio de vingança. O mesmo princípio de justiça funciona nos dois casos: a reciprocidade violenta, a retribuição. Ou esse princípio é justo e a justiça já está presente na vingança, ou então não existe justiça em lugar nenhum". ${ }^{3}$ Portanto, há sempre vingança na justiça e, da mesma forma, há sempre justiça na vingança.

Desde o imaginário social grego, da mitologia ao pensamento de Aristóteles, parece evidente que na punição residiria precisamente esse princípio de vingança. Punir é, pois, antes de tudo, vingar. Mas não simplesmente uma vingança cega e mortífera tal qual o modelo imposto pelo talião, do olho por olho, dente por dente, mas uma vingança ética. E, nessa medida, a partir de uma filosofia da punição, e tendo como pano de fundo o filme Bravura Indômita, sobretudo as significações projetadas pela personagem Mattie Ross, no espectro de seu horizonte existencial e histórico, este texto busca traçar algumas linhas divisórias que permitem antever os traços principais que diferenciam a vingança destruidora e mortífera e as dimensões de um imaginário punitivo situado nas representações simbólicas de uma ética da vingança. Portanto, debater com mais precisão as fontes imaginárias da Justiça Penal articuladas pela filosofia ética da vingança constitui o objetivo central do texto.

\section{"O SENHOR DEMONSTROU SER UM HOMEM DE BRAVURA INDÔMITA": O RELATO ARCAICO DO INDOMÁVEL DESEJO DE VINGANÇA}

O desejo indômito de vingança da menina Mattie Roos expõe, de modo preciso, as fontes imaginárias de um sentimento presente desde os relatos ancestrais da mitologia grega. Ressoa, desde então, como verdade 
quase inquestionável, o alerta de que a violência é de todos e está em todos. Grandes heróis, sejam eles deuses ou humanos, violentos, vingativos, temidos, implacáveis, são presença constante no universo mitológico. Desde o crime inaugural de Kronos, que castra o pai para permitir a origem do cosmos, ao libertar Gaia do desejo insaciável de Urano, o universo move-se sobre o terreno inóspito da consagração da vingança e da eclosão permanente de novas violências, já que são das gotas do sangue de Urano que brotam as Erínias, as deusas dedicadas à recordação do crime e à exigência de vingança, de alguma forma de reparação. ${ }^{4}$

Nas sociedades primitivas, etnólogos e antropólogos relatam que a violência é um componente básico, primário, da vida social, ao mesmo tempo disjuntivo, irruptivo, caótico e profano, tanto quanto agregador, permanente, ordenador e sagrado. ${ }^{5}$ Como destaca René Girard, “[...] uma vez despertado, o desejo de violência produz certas mudanças corporais que preparam os homens para luta", [de modo que] só é possível ludibriar a violência fornecendo-lhe uma válvula de escape, algo para devorar.

Nos mitos e práticas das sociedades primitivas, arcaicas, essa função era atribuída ao sacrifício, cuja "[...] função é apaziguar as violências intestinas e impedir a explosão de conflitos". Nos termos de Girard ${ }^{6}$,

[...] é a comunidade inteira que o sacrifício protege de sua própria violência, é a comunidade inteira que se encontra assim direcionada para vítimasexteriores. Osacrifício polariza sobre a vítima os germens de desavença espalhados por toda parte, dissipando-os ao propor-lhes uma saciação parcial. [...] Sacrifícios são oferecidos em nome dos mais variados objetos ou empreendimentos, principalmente a partir do momento em que o caráter social da instituição começa a desaparecer. No entanto, há um denominador comum da eficácia sacrificial, tão mais visível e preponderante quanto mais viva for a instituição. Este denominador é a violência intestina: as desavenças, as rivalidades, os ciúmes, as disputas entre próximos, que o sacrifício pretende inicialmente eliminar; a harmonia da sociedade que ele restaura, a unidade social que ele reforça. Todo o resto decorre disto.

No entanto, quando a violência intestina recalcada pelo sacrifício revela sua natureza, ela sempre se manifesta sobre a forma da vingança de sangue, ameaça terrificante, intolerável, que tende a espalhar-se e 
a dilacerar todo o corpo social. O relato arcaico da vingança sinaliza quase uníssono que,

Face ao sangue derramado, a única vingança satisfatória é o derramamento de sangue do criminoso. Não há diferença nítida entre o ato que a vingança pune e a própria vingança. Ele é concebido como uma represália, e cada represália invoca uma outra. Muito raramente o crime punido pela vingança é visto como o primeiro: ele é considerado como a vingança de um crime mais original. ${ }^{7}$

Por essa razão, é preciosa a advertência de François Ost no sentido de que, da mesma forma que é impossível atingir-se um ponto zero do Direito, uma vez que toda juridicidade pressupõe um plano de interação e de reconhecimento intersubjetivo prévio, poderíamos defender: "há crime antes do crime". Sendo assim, "[...] os homens terão sido sempre já confrontados com a violência; existe um futuro anterior do mal, como existe um futuro anterior da legitimidade". Com efeito, "[...] a esta anterioridade do crime responde a perenidade da memória punitiva; se não a sua perenidade, pois no universo moderno intervém a prescrição, pelo menos a sua longa duração. Punir é, pois, antes do mais, recordar". 8

Vingar e recordar, eis as mais remotas fontes do imaginário punitivo. É indispensável, pois, a partir dessa visualização inicial, restabelecer o sentido perdido da vingança. Não para fazer dela um pleno direito, mas para tentar percebê-la não apenas na sua inevitável imanência, ou seja, no fato de que, nas representações simbólicas punitivas, “[...] não há nenhum princípio de justiça realmente diferente do princípio de vingança", ${ }^{9}$ e sim para ver nela uma inversão de sinal, retirar dela uma substância ética.

Nas águas revoltas desse imaginário, o sentido da vingança vai produzindo suas metamorfoses. Imperativo ético de justiça, ideal compartilhado por deuses e por homens, cravado nos relatos mitológicos sobre a origem do cosmos; ou um mal a ser expurgado, um perigo sempre à espreita a ser intermitentemente vigiado, um demônio a ser esconjurado, a vingança sempre foi pensada como o outro lado da pena. Com efeito, nas precisas palavras de Frédéric Gros, 
[...] no nosso sistema maior de representações, para se poder punir é necessário primeiro renunciar a vingar-se. Conhece-se a história de cor: os primeiros homens, para lavarem as afrontas e punirem os crimes, conheciam apenas a vingança. Eles próprios aplicavam a justiça. Sistema de represálias: por uma injúria sofrida, faziam-se sofrer mil outras que por seu lado reclamavam ser vingadas. Guerra de todos contra todos. Turbilhão indefinido de violências. Despedaçamentos intermináveis e ódios eternos. Para contrariar este caos, os homens um dia inventaram, instauraram um Estado de Direito, Estado que aplica uma justiça serena e põe termo aos conflitos ancestrais. Estado que instaura uma legislação penal equitativa. ${ }^{10}$

Engendrado mais precisamente na era moderna, esse sistema maior de representações corresponde à emergência do Estado centralizado e burocrático, cumprindo a função de justificar o confisco do conflito e da justiça ou da violência legítimas. Foucault assinala que esse ideário marca precisamente a necessidade da superação do modelo jurídico de tipo germânico presente no feudalismo, pelo qual o Direto é uma forma regulamentada de fazer a guerra, mas sempre e apenas entre dois sujeitos, jamais três. Nesse modelo, não havia intervenção de nenhum representante da autoridade. O Direito é a forma ritual da guerra. Entretanto, nessa batalha, é sempre possível um acordo, uma transação, uma compensação financeira, uma reparação. Pode-se interromper a série de vinganças com um pacto. Assim, o sistema que regulamenta os conflitos e litígios nas sociedades germânicas antigas, revitalizado no período feudal, era governado pela luta e pela transação; é uma prova de força que pode terminar em uma transação econômica. Trata-se de um procedimento que não permite a intervenção de um terceiro neutro, procurando a verdade, tentando saber qual dos dois disse a verdade. ${ }^{11}$

Desse modo, antes de representar um elemento disforme e monstruoso, imagem do estado de natureza caótico, a vingança sempre exigiu procedimentos de regulação. Mesmo o conflito sangrento, mortífero, apresenta suas regras, seus mecanismos de autocontenção. Novamente seguindo as pegadas de Gros: 
[...] o que condena a vingança privada a ser destruidora é que ela é precisamente privada e mais precisamente ainda fora da lei, interdita, secreta. Por ser mantida secreta, a vingança priva-se talvez de poderosos mecanismos de regulação. Porque o secreto provoca terror. De tal maneira que o que hoje se chama vingança não seria senão o remanescente de uma forma ultrapassada de violência, ferozmente erradicada desde que se tenta ressurgir como uma lembrança sombria dos tempos de barbárie, mas uma forma degradada de um sistema arcaico de vingança, ele sim regulador e criador de solidariedade, na ausência sem dúvida de ser fundamentalmente pacificador. ${ }^{12}$

Mattie vive numa América do Norte de modernidade incipiente, de Estado de Direito em vias de consolidação plena. Os influxos do pensamento penal europeu são inevitáveis, a despeito da diferença de matrizes jurídicas. A vingança de sangue está quase completamente confiscada pelo Estado, a disputatio do Direito germânico já cedeu gradativamente lugar à inquisitio romano-penitencial-canônica. Nesse novo modelo, a busca da verdade pelo inquérito é prerrogativa dos agentes estatais, a acusação é impulsionada e conduzida pela figura do Procurador, representante do soberano, que exige a aplicação de uma justiça verticalizada, imposta do alto e exercida pelos juízes e cidadãos notáveis (jurados), neutros e imparciais, que proferem o veredicto em nome de toda a comunidade, já que a violência, antes vista como dano a um terceiro agredido (vítima), assume também a forma da infração à lei do Estado. Trata-se, pois, de um ataque não a um indivíduo, mas à própria lei do Estado. Assim, na noção de crime da modernidade liberal-individualista, a ideia de dano é substituída pela de infração. A infração não é um dano cometido por um indivíduo contra outro; é uma ofensa ou lesão de um indivíduo à ordem, ao Estado, à lei, à sociedade, à soberania, ao soberano. A infração é uma das grandes invenções do pensamento medieval e posteriormente racionalizada pelo pensamento penal liberal e iluminista. ${ }^{13}$

No entanto, resquícios de uma vingança de sangue sempre insistem em atuar no interior da ordem jurídica, tanto na figura dos $U$. S. Marshals, dos caçadores de recompensas, sempre na fronteira entre a representação da lei e a justiça privada, quanto na figura dos suplícios, 
dos enforcamentos como pena modelar. Violência dos crimes que o Estado ludibria, responde com "algo para devorar". Ao tentar subtrair da vítima o conflito, o Estado assume o papel da vítima por excelência, abstrata, acionando o discurso que legitima a sua supremacia, a ideia de que só ele pode conter o turbilhão das violências recíprocas, da guerra de todos contra todos, que os ódios da vítima real tenderiam a impulsionar. Discurso nitidamente desmascarado pela forma caricatural, seletiva, abusiva e também caótica, pela qual o Estado realiza a vingança pública por meio do espetáculo dos suplícios, obediente a uma determinada economia política do castigo forjada pelo poder soberano.

Não obstante, a menina Mattie descansa uma fé incansável no Direito. Exige com veemência o cumprimento dos acordos, briga sempre com o Direito ao seu lado e faz questão de repetidamente lembrar aos oponentes: "Eu tenho um bom advogado que pode...". Apesar de estar envolvida no manto da vingança, ela sempre reivindica o amparo da lei pública. Ao perceber que Marshal Cogborn vislumbra a possibilidade de um acerco com o oficial La Boeuf para encaminhar o criminoso à Justiça do Texas, motivado pelo valor da recompensa, Mattie começa a deixar clara a diferença entre aquilo que considera uma vingança justa, ética, poder-se-ia dizer, e uma vingança cega, mortífera, meramente pessoal e, por isso, inadmissível, inaceitável. No acampamento, logo ao amanhecer, desconfiada do acordo, Mettie desafia a autoridade de Cogborn: "Percebi que você e o Sr. La Boeuf fizeram um... algum tipo de acordo. E, como sua empregadora, acredito que tenha direito de saber os detalhes".

O termo "empregadora", por ela utilizado já no início da conversa, invoca de plano uma relação jurídica, pretendendo marcar os exatos contornos da relação entre ambos, o que lhe dá o "direito de saber os detalhes". Profundamente incomodado, Cogborn rebate: "Detalhes? Vamos entregar Chaney para o magistrado em San Saba, no Texas, onde há uma recompensa considerável que vamos dividir". Indignada, Mattie contra-ataca: "Não quero que ele seja levado para o Texas, para ter uma punição administrada pelo Texas por um crime cometido no Texas. Isso não foi o nosso acordo". O velho repele a afirmação: “O que quer é que ele seja capturado e punido". Mattie contrapõe: “Quero 
que ele saiba que está sendo punido por ter matado o meu pai". Cogborn contrasta e propõe: "Pode fazê-lo saber disso. Pode dizê-lo na cara dele. Pode cuspir nele, pode fazê-lo comer terra da estrada. Eu o seguro. Vou the dizer o que faremos. Vou arrancar a sola dos pés dele e encontrar uma pimenta índia para poder esfregar na ferida. Isso não vale cem dólares?". "Não, não vale. Quando eu pago por um serviço, ele tem que ser feito do meu jeito. Por que acha que estou pagando, se não vai ser do meu jeito", repele Mattie.

O diálogo prossegue em tom tenso, já que Cogborn acredita tratarse apenas de um mero capricho egoísta de menina de posses. E contesta: “Está na hora de você aprender que nem tudo pode ser do jeito que quer, nos mínimos detalhes. Se acha que eu não cumpri com os seus termos, devolverei o dinheiro no final da expedição". A despeito da postura correta de Marshal Cognorn, Mattie quer fazer valer o acordo celebrado, cuja metade do pagamento já fora adiantado: "Pretinho e eu vamos reclamar à administração. Isso é fraude". $\mathrm{O}$ velho não segura a irritação: "Mil Diabos", esbraveja. Nesse instante, La Boeuf interrompe: "O que está acontecendo?”. “Uma conversa de negócios", responde Cogborn. “É assim que chama? Para mim parece que ainda está sendo manipulado pela garotinha", ironiza o cavaleiro texano. Mattie intromete-se e sentencia, pondo um fim à discussão: "Não há manipulação. O meu acordo com Marshal é anterior ao seu. Tem força de lei" (grifei).

Toda esta batalha argumentativa, travada entre os principais protagonistas da saga de vingança, é profundamente reveladora. Mattie ancora-se a todo instante na lei, na força do seu acordo com Cogborn para exigir que realize as coisas, "o serviço", do seu jeito. Notavelmente, quanto pleiteia que tudo seja feito do seu jeito, é da punição pública que se trata. É a pena capital imposta pelo tribunal que ela convoca. Ademais, ela quer que ele saiba que está sendo punido por ter matado seu pai. Quer tornar público o seu sofrimento, aos olhos do criminoso e de toda a comunidade.

Isso fica claro quando exige que a punição não se realize no Texas. Três vezes Texas, ela pronuncia na mesma frase, o que denota a importância que atribui ao local da publicização dos atos punitivos. Para ela, Chaney deve ser punido em Fort Smith, no seio da comunidade a qual pertence. Nenhuma outra vingança pessoal a satisfaz, nenhuma vingança privada 
pode substituir os rituais e a publicidade do enforcamento público que ela demanda. Apenas "dizer na cara dele", "cuspir nele", "fazê-lo comer terra na estrada" ou "arrancar a sola dos pés dele e encontrar uma pimenta índia para poder esfregar na ferida", como oferece o velho Cogborn, não satisfazem o seu horizonte simbólico da vingança. Nenhum ato dessa natureza, nem mesmo a imposição do sofrimento e da dor pode suplantar o ritual judiciário que ela reclama. E é com a "força de lei" e da "anterioridade dos pactos" (pacta sunt servanda) que ela pretende fazê-lo. Por isso, ganha força sua afirmativa de que "não se trata de manipulação".

O sentimento de vingança que a move não apresenta o semblante de uma selvageria caótica, que ela, inclusive, veementemente recusa. Não quer violentar, humilhar, torturar, fazer calar com terra o malfeitor. Quer, na verdade, entregá-lo ao juiz Parker para que seja julgado segundo as leis e enforcado no pelourinho em Fort Smith. É de uma vingança distinta que se trata, não meramente talional, do olho por olho, dente por dente. Se o fosse, um único tiro de rifle poria fim ao caso.

\section{A VINGANÇA RESSIGNIFICADA}

Como perceberam, por meio de pesquisas transdisciplinares realizadas a partir de 1974, Raymond Verdier e G. Courtois, é possível reconduzir a vingança à solidariedade, propondo regras a regulamentála: o sistema vindicatório ou justiça vindicativa. Tais pesquisas trataram então de perquirir e pensar "uma vingança que solidarizasse ao invés de despedaçar, que ordenasse ao invés de destruir, que fixasse regras e medidas em vez de entregar os seus atores ao imediatismo selvagem e impuro da violência cega". Nesse sentido,

[...] fica então denunciado o muito de uma vingança presumida na aurora do Estado como uma noite sem fundo, de uma vingança como infância monstruosa de uma humanidade pré-social e pré-jurídica. Esta vingança, garante R. Verdier, é como o estado de natureza dos filósofos. Ela não se pode encontrar porque procede de uma concepção moderna posterior à instauração do Estado. ${ }^{14}$ 
Na sua saga, parece ser essa forma de vingança que a menina Mattie deixa transbordar. $O$ fato de exigir o enforcamento público, segundo as leis aplicadas pelo tribunal, sinaliza a recusa das violências privadas, as quais ela teve a chance de anuir e executar. Não se trata simplesmente de fazer exemplos aos outros; o que ela almeja é aquilo que R. Verdier vislumbra como uma justiça que quer, sim, que se pague o mal com o mal. Porém, uma justiça que, longe de pertencer, como refere o autor, às idades da barbárie, era de uma natureza mítica e divina, possuindo sempre a sua dose de razão e não tão somente de paixão. Poder-se-ia propor um relato ideal da justiça vindicativa, desde a aurora grega, num tempo em que a jurisdição familiar preponderava, da seguinte maneira: o dano que atinge um homem estende-se a todo o seu clã, inaugurando uma vingança de sangue. Ante a humilhação e a cólera, dever-se-ia, portanto, vingar o mal causado, constituindose tal obrigação como imprescritível e definitiva. Na realidade, uma declaração de guerra. Contudo, poder-se-ia perdoar a vingança de sangue mediante compensação pecuniária, por obra de um "ato de composição" (poinê), que primeiramente era fixada pelo clã, dando origem a um tratado de paz pública ritualizado, e, após, pelo próprio Estado. ${ }^{15}$

Nesse ponto, são importantes alguns questionamentos. A compensação da vingança de sangue por pecúnia

[...] é o preço do sangue derramado ou do sangue poupado? A fortuna que uma família consente em receber é um equivalente monetário da vítima ou um resgate pela vida salva do ofensor? Punir consiste em receber uma indemnização equivalente do dano ou fazer-se pagar constitui uma compensação pelo que se renuncia a punir e que se aceita perdoar? No primeiro caso, há um preço do crime. E no outro um preço do perdão. A questão é histórica sem dúvida, mas a resposta é ética. ${ }^{16}$

Deve-se perceber que o ato do perdão não é eficaz a constranger o infrator à culpa moral, em virtude da ausência de sua pureza, que tem um preço. A vingança primitiva tem como característica a obrigação: punir é um “[...] dever absoluto, imprescriptível, dever hereditário e 
partilhado" e não um direito do qual se pode abrir mão. A explicação reside justamente no fato de ser a vingança sagrada e eminentemente religiosa. Assim, é entendida como uma dívida de sangue, honra, vida, forças e riquezas, que o infrator contrai com a vítima. Em contrapartida, a vítima credora somente consegue se reestruturar quando repetido o ato que a lesou ou por meio da compensação, equivalente metafórico das riquezas materiais, tal como o sangue e a honra. "O sangue não envelhece", afirma um ditado abekhaze citado por R. Verdier. A recuperação da integridade do lesado e a consequente estabilidade pressupõem a subtração do equivalente do infrator. ${ }^{17}$

Diante disso, não há na vingança primitiva a maldade, o ódio, a humilhação, ou a memória dolorosa, mas tão somente existe para recuperar a honra perdida, para cumprir uma obrigação e para conformar-se ao rito. Com efeito,

[...] não se vinga para se curar de uma dor que de outra forma ficaria aberta. Não se vinga para garantir o que Freud chama 'ab-reacção', a libertação de um afecto ferido. Vinga-se para honrar um morto, para cumprir uma obrigação familiar, conformar-se a um rito. A vingança impõe-se como dever sagrado, obrigação ritual do que como instinto mortífero ou urgência sanitária. Ela dá-se a pensar como obrigação ritual e não como mecanismo psicológico de compensação. ${ }^{18}$

Por outro lado, tem muito pouco a ver com a humilhação. Isso porque o sistema puro da vingança “[...] não é uma lógica de guerra, é uma lógica da rivalidade [...]", que pressupõe, além da capacidade de rivalizar, o reconhecimento, a igualdade e equilíbrio de forças entre vítima e agressor, para que ambos possam se comunicar entre si e com os seus. De igual modo, o que está em jogo não é de maneira alguma a ordem do ódio. O que o liga vítima e agressor não “[...] é um afeto negativo cujo poder inundaria o vingador e que o ameaçaria em resposta". Trata-se, antes de tudo, de uma dívida que é preciso saldar. Compreende-se antes nos termos da troca. Algo que é preciso pagar: “[...] pagar golpe por golpe sem dúvida, mas pagar e não destruir. Vingar-se é fazer-se restituir, e restituem-se bens e honra. Restitui-se o 
poder e os mortos". ${ }^{19}$

Finalmente, a vingança não está de modo algum aprisionada a uma memória dolorosa. É precisamente do contrário que se trata: “[...] não se vinga para produzir um acto solene que seja como a perpetuação dolorosa do crime sofrido. Não se vinga para ilustrar uma memória do luto. Pelo contrario, vinga-se para se poder esquecer" ${ }^{20}$ Em outras palavras, a estrutura da vingança não implica lembrança de uma dor, mas uma forma de esquecê-la, por meio de um ato solene e ritualizado que aufere o sentido de justiça. O esquecimento exige e proclama os seus rituais e as suas cerimônias públicas, além da manifestação do tempo. $\mathrm{O}$ esquecimento, muito para lá de um evento meramente temporal, decidese, proclama-se, consiste numa tomada de posição ética.

Sem embargo, na percepção da sociedade moderna, em que pese justa, a vingança não é sinônimo de justiça. No paradigma penal da modernidade, o reconhecimento da vítima sempre esteve atrelado a essas imagens negativas e monstruosas: a malvadez, a humilhação, o ódio e a memória dolorosa. O papel reservado à vítima na dramaturgia penal restringia-se a fazer-se ouvir, como coadjuvante escondida, por meio "[...] do grito odioso da malvada vingança". Nesses termos, reconhecer o sofrimento da vítima era condenar-se então a deixar penetrar no tribunal o veneno negro de uma violência incontrolável, própria para nos fazer entrar num turbilhão de ódio. Este risco era necessário medi-lo retomando o relato da vingança". É nesse sentido que

[...] esse relato da vingança, que devia confortar-nos na recusa de fazer participar activamente a vítima no sentido da pena, fez surgir outras figuras éticas; não a maldade instintiva, mas o dever ritualizado; não a humilhação, mas o desafio; não o ódio, mas a troca; não a comemoração dolorosa, mas as cerimônias do esquecimento. Entretanto, é necessário tomar esse relato da vingança por aquilo que ele é, um relato precisamente. Não se trata de exaltar a vingança nem de lhe defender os direitos. Trata-se de dizer simplesmente que no cenário arcaico da vingança tal que os historiadores da Grécia pré-arcaica e reconstituíram, no que os etnólogos chamam o 'sistema vindicatório', há o traçado em oco de um certo sentido de justiça, cujos relatos de vingança organizam a aplicação em cena 
exterior. Como epopéia, a vingança é o símbolo exterior de um sentido do justo. Para lá do relato, é este sentido que precisamos agora de reencontrar. O que é que torna justa a vingança? Porque, para não ser justiça, a vingança continua entretanto justa. E é ao repensar o sentido desse justo que poderá esclarecer-se o sentido de uma nova justiça: percurso do justo vindicativo à justiça relacional. ${ }^{21}$

No Ocidente, porém, ainda vige a ideia de que somente por meio da renúncia à vingança se pode operar a justiça e a punição, não obstante existirem textos éticos que descrevem a justiça vindicativa, principalmente os escritos de Aristóteles e Nietzsche.

\section{MATTIE ROSS NA ENCRUZILHADA DE MONTANHAS TORTUOSAS: ENTRE A PICADA VENENOSA DA VINGANÇA DE SANGUE E OS ESFORÇOS PELO JUSTO VINDICATIVO E PELA JUSTIÇA RELACIONAL}

Após uma emboscada malsucedida, na qual os criminosos logram escapar, uma acirrada discussão entre o grupo no acampamento noturno praticamente fulmina a continuidade da expedição, para o desespero da menina Mattie. Ao amanhecer, no entanto, a menina dirige-se ao rio na busca de água e avista surpreendentemente Tom Chaney do outro lado da margem, refrescando-se e dando água aos cavalos. O fugitivo olha em sua direção, aproxima-se devagar e afirma admirado: "Sei quem você é. Seu nome é Mattie. É a pequena Mattie, a escriturária. Que coisa". A menina reage imediatamente: "Sim, e eu sei quem você é, Tom Chaney". O criminoso indaga: "O que está fazendo aqui?". Despistando, como se quisesse esconder o mérito da questão que os envolvia, a menina responde: "Vim buscar um pouco de água". Chaney insiste: "Não, o que está fazendo aqui no meio dessas montanhas?". Mattie, finalmente, revela o motivo de sua presença em local tão distante e inóspito: “Embora isso não seja oficial, estou agindo em nome do Marshal Rooster Cogborn e da corte do juiz Parker. [...] 
Estou aqui para levá-lo de volta a Fort Smith. [...] Se você se recusar, terei de atirar".

O encontro inesperado e forçado com o assassino de seu pai estabelece uma espécie de gênese oca, disforme, simples arremedo de justiça relacional, colocando vítima eagressor frente a frente. A ausência de um mediador, de um ritual público, de regras e procedimentos, no entanto, inviabilizam qualquer possibilidade de restauração, pois autoriza a prevalência da vontade do mais forte.

Chaney se recusa, por óbvio, a observar o comando de uma menina e parte em sua direção a fim de impor-se pela violência. Mattie, porém, está armada, insiste na rendição do criminoso e desfere o tiro no limite de sua derrocada. Aqui fica claro que Mattie poderia, simplesmente, disparar logo contra o fugitivo, deixar correr pelas veias seu ódio, pondo fim ao seu desejo de vingança. Mas não é isso que se vê. Ela, na verdade, pretende apenas levá-lo a Fort Smith e diz estar agindo em nome de Marshal Gogborn e da corte do juiz Parker. Quer, a todo custo, um vingança distinta, com um certo apelo ético. $O$ disparo atinge o ombro de Chaney que se mantém de pé e avança em sua direção. Mattie tenta o segundo disparo, mas a arma falha. O criminoso, então, consegue dominá-la e trazê-la para junto de seu bando.

O temido bandido Luck Ned, chefe da quadrilha, passa então a mediar o conflito. Impede que Chaney aja com violência contra a menina e se propõe a ouvi-la: “O que houve?", indaga. Calmamente, e com a bravura de sempre, Mattie desafia o chefe do grupo e expõe os fundamentos de fato e de direito de sua pretensão vindicativa: "Vou lhe dizer e você vai ver que eu estou com razão. Tom Chaney matou meu pai em Fort Smith e roubou duas peças de ouro e sua égua. Me informaram que o Sr. Cogborn era bravo e o contratei para encontrá-lo. Há pouco vi Chaney dando água aos cavalos. Ele não quis vir por bem, então eu atirei nele. Se o tivesse matado, não estaria nessa situação, mas o revólver falhou". O criminoso, admirado, responde: "Isso basta. Vai atrapalhá-la para sempre. A maioria das meninas gosta de brincar com enfeites, mas você gosta de armas?". Mattie rebate: “Eu não dou a mínima pra armas. Se gostasse, teria uma que funcionasse". Nesse momento do diálogo, Chaney se intromete, meio envergonhado, dizendo: "Levei o tiro numa emboscada, Ned. Os cavalos estavam 
fazendo barulho, foi o oficial que atirou em mim". Imediatamente, em tom exaltado, Mattie dispara: "Como pode contar uma história tão mentirosa?". Chaney perde a compostura e parte para a ameaça: “Esse buraco tem 30 metros. Eu vou jogá-la nele e deixá-la gritando até apodrecer. O que acha disso?". Ned interrompe a discussão: "Você não vai". A menina completa, reafirmando a autoridade do poderoso chefão: "Esse homem não vai deixá-lo fazer o que quer. É seu chefe e tem que fazer o que ele disser".

Também aqui, nesse embate argumentativo, toscamente mediado pelo chefe do bando criminoso, Mattie invoca a autoridade da lei, relata os fatos delituosos que exigem vingança, reparação e destaca que só atirou em Chaney porque "ele não quis vir por bem". De novo, a vingança de sangue não era o seu alvo. Buscava algo além do olho por olho. O seu desejo efetivo era encaminhá-lo ao tribunal. Não dá a mínima para armas. Ela prefere a regra, a composição, o acordo, o rito, o sacrifício. De novo, quer deixar público, ainda que aos olhos tortos e assustadores de Luck Ned, os acontecimentos, não aceitamento as mentiras relatadas por Tom Chaney. Quer, acima de tudo, reafirmar aos olhos de todos a sua estima, o equilíbrio partido pelo dano causado por Chaney.

A atitude da menina Mattie Ross enuncia que a vingança contém sim uma substância ética, que ultrapassa o golpe por golpe, o sangue por sangue. Há sim justiça na vingança, assim como há também vingança na justiça. E a justiça da vingança consiste precisamente nessa busca do si, que restitui a identidade e o reconhecimento intersubjetivo.

É precisamente Aristóteles quem nos oferece um conjunto magistral de lições a esse respeito. A arquitetura lógica de seu pensamento é consagrada na sua primeira afirmação sobre da justiça. Diante de sua concepção de comunidade política e de sua percepção acerca da dignificação do homem, a justiça, como "[...] un ejercicio de la virtud perfecta" é talhada pelas mãos da igualdade. Aristóteles registra, logo na abertura do famoso Livro V, de sua Ética a Nicómaco, que "[...] lo justo es lo legal e lo igualitario, y lo injusto es lo ilegal y lo no igualitario". Julgar é, pois, igualizar, restabelecer uma igualdade desfeita, dilacerada. ${ }^{22}$ 
A justiça, amparada em leis elaboradas por homens livres e iguais, sempre tendo em vista o bem da comunidade, pode ser vislumbrada como "virtude perfeita" apenas quando tecida concretamente, no âmago dos conflitos reais. Segundo ele, "[...] esta justicia es una virtud perfecta, mas no en términos absolutos, sino en-relación-con-otro". Trata-se, pois, de uma virtude construída a partir de uma relação concreta, jamais possível de ser definida e apreendida de modo matemático, desencarnado, abstrato, absoluto, transcendente.

Por conseguinte, para Aristóteles, afirma Frédéric Gros, o ato de punir não se desenha meramente com esse esquadro aritmético. Enraíza-se, na realidade, na situação ética da vingança. Com efeito,

[...] esta raiz ética é a cólera. A exigência de punir procede não de um sofrimento a apaziguar mas de uma cólera a honrar. É aqui que é necessário retomar a definição precisa da cólera em Aristóteles: ela é, escreve ele na Retórica, 'um desejo sombrio (orexis meta lupes) de vingança pública (timôrias phainomenês) face a uma manifestação pública de desprezo (phainomenên oligôrian) pela nossa pessoa ou pela dos nossos, sendo imerecido este desprezo'. Leibniz retomará esta definição quase à letra: 'a cólera é um desejo de prejudicar que responde a um desprezo'. [...] A origem ética da vingança é então menos o sofrimento que a cólera. A raiz ética do crime é menos a violência que o desprezo. ${ }^{23}$

Nessa trilha, a raiz ética do crime é o desprezo, a ausência de reconhecimento (HONNETH), ou o "bloqueio do rosto" (LEVINÁS), pois que a agressão e o delito não visam jamais apenas corpos ou riquezas. O que o ato criminoso proclama, na sua vertente ética, é precisamente a manifestação de um desprezo público do agressor enquanto, atacando-nos, detém o nosso poder para nada. Não se pode esquecer, todavia, que, no modelo descrito por Aristóteles, há uma separação estrutural entre indivíduos. Para Aristóteles, o igual, que podia se munir de cólera, somente se configurava como o cidadão livre. Desse modo, a origem da vingança reside justamente na cólera a busca pela honra - e não no sofrimento. Por sua vez, a origem ética do crime é calcada no desprezo e não na pura violência, visto que a 
conduta do agressor reside no desprezo público para a vítima. Nesse ponto, a cólera da vingança é considerada necessária e apta a restaurar a imagem pública agredida, ao passo que a sua ausência é equiparar-se a um escravo. Nas palavras de Gros,

[...] a cólera da vingança, enquanto responde a um desprezo, não é então considerada aqui uma violência lastimável da alma ou uma marca e uma incapacidade em se dominar. Encolerizar-se não é ceder aos instintos de violência, mas pôr em jogo a sua imagem pública. A cólera designa a energia própria a restaurar uma imagem exterior de si seduzida pela agressão. É por isso [que] a ausência de cólera é fortemente condenada: 'passa-se então por não se sentir a ofensa e de não lhe experimentar nenhuma pena e, a partir do momento em que não se consegue encolerizar, por ser incapaz de se defender. Ora, quando se é difamado, suportá-lo e se são os nossos próximos, encará-lo com indiferença é, aos olhos de todos, ter uma alma de escravo'. [...] Ao recusar-se ceder à cólera, perde-se a dignidade e a honra de ser-se homem, ou, mais precisamente, para Aristóteles: o seu estatuto de ser-se livre e de cidadão. $\mathrm{O}$ que permanece indiferente à ofensa justifica-a. ${ }^{24}$

Não é, então, a vingança, um ato que busca restabelecer a igualdade entre as partes, entre o ofensor e a vítima? Ademais, para que se possa operar a vingança, deve haver um reconhecimento: para que possa ter ocorrido um desequilíbrio, é necessário que tenha havido primeiramente uma igualdade. Nesses termos, a cólera é sistematicamente pensada como o que reafirma, em face a um ato de maldade, a dignidade social do ofendido. De outra forma, encolerizar-se a respeito de tudo e de nada é igualmente condenável aos olhos de Aristóteles, mas o excesso de cólera parece preferível à sua ausência completa. Ultrapassar toda a medida, vingar-se a propósito de tudo e de nada é perder de vista a nobreza da vindicação. Na mesma esteira, Nietzsche, ao descrever a vendetta - duelo entre adversários iguais - estabelece a diferença entre adversário e inimigo. Somente contra aquele se pode vingar. Contra este, cabe somente a defesa. ${ }^{25}$

Com efeito, a grande característica da vingança é a busca do si. Como forma de equilibrar uma relação posta em desigualdade por uma 
ofensa, não se vinga por crueldade ou prazer, mas pretende-se, além da restauração da imagem pública, a própria imagem do si para si: recuperar a confiança em si e a integridade ofendida, sem a qual a consequência só poderia ser uma, o desprezo próprio e mutilador. A atividade própria da construção da identidade, da estima de si, estruturada sempre numa relação ativa com um outro, exige-a. Nesses termos, a vingança, refletida no seu sentido estritamente ético coloca em ação essa estruturação do si em face do trágico do encontro infeliz. Ela baseia-se nessa operação de busca do equilíbrio, pois restitui, restaura, igualiza relações. A vingança se dedica a restaurar uma imagem social do si, esse si cuja integridade foi despedaçada, inquietada pela agressão. A lição ética da vingança, diz Gros, é bem clara: “[...] vingar-se é manifestar publicamente o seu poder e, por essa manifestação, recuperar uma estima de si inquietada" ${ }^{26}$

A vingança é, por conseguinte, o exercício de uma atividade em retorno (antipoiesi). Assim,

[...] a vingança compreende uma antipoiêsis, isto é, afirmação de poder de si e atribuição de valor em relação àquele que a põe em causa. Com efeito, o que um crime, uma injúria, uma ofensa, um delito despedaçam é para já a confiança na sua integridade, uma integridade dinâmica e vital. Ter-se tornado objecto de violências, sejam físicas ou verbais, faz perder a confiança em si, na sua capacidade de actuar e de viver segundo seu próprio fundo. É necessário absolutamente reagir para já não ter de duvidar de si, para não ter de se desprezar. Porque sem vingança, sem resposta, o desprezo de que o ofensor faz prova ao atacar-nos parece então justificado e torna-se desprezo de si mesmo. Não se vinga por crueldade mórbida, prazer suspeito ou cólera desenfreada, mas para reconquistar a estima de si, prevenir o desgosto de si mesmo. ${ }^{27}$

Nesse ponto, a cólera vingadora, na sua nobreza ética, é o primeiro passo dessa reconquista. Isso porque Aristóteles teve o cuidado de anunciar a fundamental distinção entre cólera (orgê) e ódio (ekhtra). Diz ele que o tempo pode curar a cólera (iaton khronô); o ódio é incurável; a cólera resulta de ofensas que interessam à nossa pessoa (tôn pros auton); mas o ódio pode ser experimentado mesmo sem nenhuma razão pessoal (aneu tou pros hauton)'. Segundo Gros, 
[...] o que diferencia a cólera do ódio é então a maneira como o si (hauton) se recompõe, impondo uma objecção ao outro. Na cólera, o si estrutura-se e redefine-se a partir de um outro si que havia ferido e ao qual ele opõe agora o seu poder. O ódio, por seu lado, é puro apetite de destruição. Tem a ver com as massas e os conjuntos. É pura negação, quando a cólera visa recomposições positivas do si. Aristóteles acrescenta ainda: 'a cólera é um desejo de criar a pena (lupês); o ódio um desejo de fazer mal (kakou); quem está encolerizado quer ser testemunha desta pena; isso não importa minimamente ao ódio' [...] Um homem que se vinga necessita que aquele de quem se vinga saiba de onde lhe vem o sofrimento, sem o qual este seria inútil. Porque este sofrimento não tem o seu fim em si mesmo, mas transporta em si uma afirmação de valor que exige ser realizado num espaço público, em que ele possa existir aos olhos de todos. ${ }^{28}$

Nesse sentido, ao passo que a impunidade justifica e acarreta desprezo, a cólera move a vingança, que torna o desprezo em desafio, o desafio de recuperar-se. Portanto, "vingar-se não é opor a violência à violência. Se é verdade que o contrário da violência não é a paz, mas a rivalidade. Porque a paz é sempre uma paz armada. Vingar-se não é opor golpe com golpe, numa exigência cega e obstinada de equilíbrio aritmético. Não é exacerbar a violência mas regular a adversidade". A intenção da vingança não reside, pois, na humilhação do agressor ou na oposição de violência com violência, mas promovê-lo à condição de adversário para se recuperar a própria dignidade. Assim,

[...] é ainda uma metamorfose ética que é necessário pensar. A vingança faz girar o sentido do crime: dá à agressão desprezadora o significado de desafio, à pena exigida pela cólera indignada a dimensão de recuperação da confiança em si, de uma imagem social do si de que há muito se chama 'honra'. Ao punir, não se trata de humilhar o outro, nem de o rebaixar ao ponto a que nos tinha rebaixado. Humilha-se tão pouco o outro que, de ofensor, promovemo-lo à dignidade de adversário. Não se trata de pagar ofensa com ofensa, desprezo com desprezo, humilhação com humilhação. 
Trata-se, na vingança, de reconquistar o si ao ponto em que ele estava enfraquecido. O ofensor tornou-se então um rival. E por ter transformado a ofensa em desafio, a humilhação cai para não deixar luzir senão o relâmpago da desforra. Nada de menos negativo que este apetite de justiça trazido pelas asas da cólera. O que procura a vingança repensada por Nietzsche e Aristóteles é então uma substância ética: a confiança em si, a estima de si, a dignidade..$^{29}$

As ações de Mattie Ross parecem estar guiadas por esses horizontes simbólicos. Rejeita desde o início a humilhação, o escárnio, a tortura do assassino de seu pai. Não quer cuspir-lhe na cara, esfregar-lhe pimenta nas feridas abertas nas solas dos pés pelas mãos de seu justiceiro. Não é a vingança privada, cega e mortífera que ela deseja. O seu desejo é recuperar, no seio de sua comunidade, uma imagem de si destroçada pelo ato violento de Chaney. O que ela almeja e levá-lo a Fort Smith, para que os rituais públicos de punição sigam seu curso.

Ela ainda tem tempo e disposição de espírito para conversar um pouco mais com Luck Ned, contar-lhe sobre mortes indesejadas, ocorridas no curso da expedição. Tem sensibilidade para lhe oferecer a ajuda de seu "bom advogado". Porém, os esforços pelo justo vindicativo e pela justiça relacional não prosperam. Luck Ned decide partir com seu bando, deixando Mattie sob a custódia de Chaney, que deve aguardar o anoitecer para se juntar novamente ao grupo, uma vez que não há cavalos suficientes. Nenhum dos dois acata passivamente a ideia. Chaney demonstra receio de ser capturado. Mattie revela seu medo de ser também ela morta pelo assassino de seu pai: "Não vou ficar aqui sozinha com Tom Chaney". "É assim que vai ser", responde secamente Luck Ned. A menina apela mais uma vez: “Ele vai me matar. Você o ouviu. Ele matou meu pai e agora vai deixar que me mate". Ned retruca: "Ele não vai fazer isso". E ordena em seguida: “Tom, você conhece a passagem em Cypress Forks, perto da capela? Quando for, pega a menina e deixe ela lá. Entendeu, Tom? Se essa criança sofrer qualquer mal, você não será pago".

Os dois voltam a estar frente a frente, sozinhos, sem qualquer mediação. Iniciam um diálogo, em que Mattie propõe novamente uma solução acordada, uma composição, construída pelas partes conflitantes. 
Mas Tom Chaney é realmente um homem violento. Nenhuma regra, nenhum acordo o detém. Atira Mattie ao chão e lança-se sobre ela para esfaqueá-la. No limite, o oficial La Bouef surgee desfere um golpe na cabeça de Chaney, desmaiando-o. Surpresa e aliviada, a menina pergunta: "Sr. La Boeuf, como é que chegou aqui?". “Ouvi um tiro. Desci o rio. Cogburn traçou um plano. Tome cuidado, tem um buraco ali. Sua parte temo que seja mais difícil. Ele vai atrás de Luc Ned", explica o oficial texano.

Enquanto Cogborn cerca o bando de Ned na estrada, La Boeuf e Mattie assistem a tudo do alto da montanha. A situação é difícil. São quatro bandidos contra o destemido Marshal. O tiroteio a galope inicia, Cogborn alveja todos, mas também é atingido e jogado ao chão com seu cavalo. Ned, bastante ferido, aproxima-se para matar o velho justiceiro. Lá de cima, La Boeuf acerta um tiro preciso em Ned, com a carabina Sharp, uma arma apreciada pela sua precisão. Nesse exato instante, Tom Chaney desperta do desmaio e revida o golpe, acertando a cabeça do oficial texano. Em legítima defesa, Mattie disputa com Chaney a posse do rifle, consegue ficar com ele e, finalmente, acerta o peito do assassino de seu pai, matando-o. Com o disparo, a pressão de arma de alto calibre arremessa a menina para o buraco anteriormente mencionado por La Boeuf. O buraco é fundo, escuro, e a menina despenca até ficar aprisionada em raízes e galhos no seu interior.

Vê-se, pois, que os esforços pelo justo vindicativo e pela justiça relacional cedem lugar à vingança de sangue. Se "a mancha de sangue não envelhece", a ausência de um rito sacrificial leva necessariamente ao confronte sangrento. A falta de um conduz ao encontro com o outro. "Nada nessa vida é de graça", preceitua Mattie Ross desde o início da história. Quando frustrados ou desprezados os rituais e procedimentos de reparação, de sacrifício das violências intestinas, a vingança de sangue renasce intrépida, impávida e indômita. Ninguém ludibria a violência, senão com algo que ela possa devorar. Mas ela também tem o seu preço, se nada nessa vida é realmente de graça.

Após realizar a vingança de sangue, arremessada ao fundo do buraco escuro, presa a raízes e galhos, Mattie desperta um ninho de cobras venenosas. Ela tenta desesperadamente se desprender das raízes, sem sucesso. As cobras rastejam sobre seu corpo. Nesse momento, o velho Cogborn surge e adentra o buraco sustentado por 
uma corda atada ao cavalo. Mattie, porém, é picada na mão. Cogborn corta e amplia a ferida com uma faca, e tenta sugar o veneno com a boca. La Boeuf, do lado de fora, puxa o cavalo e os retira da cratera. A cobra a mordeu. $\mathrm{O}$ veneno da vingança de sangue - o outro lado do justo vindicativo - penetrou o seu corpo, infectou o seu próprio sangue. A vingança destruidora e mortífera cobrou a fatura. Realmente, Mattie tinha razão desde o início, "nada nessa vida é de graça". Também ela pagou por isso nesta vida, de uma forma ou de outra.

$\mathrm{O}$ veneno está em suas veias. Mattie está fraca, sente vertigens. $\mathrm{O}$ médico mais próximo está muito distante. $\mathrm{O}$ caminho é longo, penoso. Pode ser que não resista. Cogborn parte em disparada com a menina no colo, ambos montados no cavalo "Pretinho". O sol se põe, a cavalgada prossegue noite a dentro. "Pretinho" está exausto. Delírios invadem seu pensamento. Não consegue lembrar-se de que matou Chaney. Acredita que o bandido está fugindo. "Pretinho" cai, consumido. Cogborn não hesita em sacrificá-lo, para desespero e dor de Mattie. O velho carrega nos braços a menina, até a exaustão de suas forças, à cabana do médico.

Um quarto de século depois, da janela do trem, a senhora Mattie recorda cada momento da saga de vingança. A picada da cobra lhe fez perder parte do braço esquerdo. O veneno da vingança de sangue cobrou, como sempre, o seu quinhão: seu querido cavalo "Pretinho" e um braço amputado. O processo do justo vindicativo, interrompido pelas circunstâncias, bloqueado pelos rumos inesperados das conjunturas factuais, atirou Mattie numa encruzilhada, em que o caminho da vingança cega acabou sendo percorrido. A reparação se fez pelo viés torto da vingança de sangue, não permitiu uma restauração plena, apta a possibilitar o esquecimento. A memória dolorosa permaneceu em vida até o fim.

\section{REFERÊNCIAS}

ARISTÓTELES. Ética a Nicómaco. Madrid: Alianza Editorial, 2003.

ARNAUD, Andre-Jean. Critique de la raison juridique. Paris: LGDJ, 1981.

BRAVUTA INDÔMITA. Paramount Pictures, 2010. 
CLASTRES, Pierre. Arqueologia da violência. Tradução de Paulo Neves. São Paulo: Cosac \& Naify, 2004.

FOUCAULT, Michael. A verdade e as formas jurídicas. 3. ed. Rio de Janeiro: Nau Editora, 2003.

GARAPON, Antoine; GROS, Frédérich; PECH, Thierry. Punir em democracia: e a justiça será!. Lisboa: Instituto Piaget, 2002.

GIRARD, René. A violência e o sagrado. 2. ed. São Paulo: Ed. Paz e Terra, 1998.

HONNETH, Axel. Luta por reconhecimento: a gramática moral dos conflitos sociais. Tradução de Luiz Repa. São Paulo: Editora 34, 2002.

MALINOWSKI, Bronislaw. Crime e costume na sociedade selvagem. Tradução de Maria Clara Corrêa Dias. Brasília: UnB, 2003.

OST, François. O tempo do direito. Tradução de Maria Fernanda Oliveira. Lisboa : Instituto Piaget, 1999.

Contar a lei: as fontes do imaginário jurídico. Tradução de Paulo Neves. São Leopoldo: Unisinos, 2004.

VERNANT, Jean-Pierre. O universo, os deuses, os homens. Tradução de Rosa Freire d'Aguiar. São Paulo: Companhia das Letras, 2008.

\section{NOTAS}

1 As falas citadas no texto são referentes ao filme: BRAVURA indômita. Direção Joel Coen e Ethan Coen. [S.I.]: Paramount Pictures, 2010. 1 DVD (110min).

2 A noção de imaginário punitivo (ou da justiça penal), aqui desenvolvida, pretende refletir o fato de que o Direito não se contenta em defender posições instituídas, mas exerce igualmente funções instituintes, "[...] o que supõe criação imaginária de significações sociais-históricas novas e desconstrução das significações instituídas que a elas se opõem". Assim, o imaginário jurídico (punitivo ou da justiça penal) se articula, pois, como um espectro de representações simbólicas em permanente tensão com as formas oficiais do Direito estabelecido ou positivo. Nesse sentido, ele repousa tanto nas formas instituídas do direito posto, quanto em um ima- 
ginário jurídico, em um direito instituinte, isto é, uma espécie de infradireito, "[...] gerador das mais diversas formas de costumes, hábitos, práticas e discursos que não cessam de agir, de dentro, sobre os modelos oficiais do direito instituído". Assim, os horizontes de sentido atribuído à pena e aos rituais punitivos são sempre decorrentes dessa tensão dialética entre formas instituídas, articuladas sob a forma de discursos de justificação dominantes, e as forças instituites, precisamente esse conjunto de discursos e práticas instituintes, que jamais deixam de questionar, combater e mesmo romper os discursos, as estruturas e as práticas estabelecidas (OST, 2004; ARNAUD, 1981).

3 GIRARD, René. A violência e o sagrado. 2. ed. São Paulo: Ed. Paz e Terra, 1998. p. 28.

4 VERNANT, Jean-Pierre. O universo, os deuses, os homens. Tradução de Rosa Freire d'Aguiar. São Paulo: Companhia das Letras, 2008. p. 10 e segs.

5 CLASTRES, Pierre. Arqueologia da violência. Tradução de Paulo Neves. São Paulo: Cosac e Naify, 2004. MALINOWSKI, Bronislaw. Crime e costume na sociedade selvagem. Tradução de Maria Clara Corrêa Dias. Brasília: UnB, 2003.

6 GIRARD, 1998, p. 19-20.

7 Ibid., p. 27.

8 OST, Franç̧ois. O tempo do direito. Tradução de Maria Fernanda Oliveira. Lisboa: Instituto Piaget, 1999. p. 127-128.

9 GIRARD, op. cit,. p. 28.

10 GARAPON, Antoine; GROS, Fréderich; PECH, Thierry. Punir em democracia: e a justiça será! Lisboa: Instituto Piaget, 2002. p. 114.

11 FOUCAULT, Michael. A verdade e as formas jurídicas. 3. ed. Rio de Janeiro: Nau Editora, 2003. p. 58.

12 GARAPON; GROS; PECH, 2002, p. 116.

13 FOUCAULT, op. cit. p. 63 e segs.

14 GARAPON; GROS; PECH, op. cit., p. 116.

15 Ibid., p. 116-117.

16 Ibid., p. 118.

17 Ibid., p. 119. 
18 Ibid., p. 121.

19 Ibid., p. 121.

20 Ibid., p. 122.

21 Ibid., p. 122.

22 ARISTÓTELES. Ética a Nicómago. Madrid: Alianza Editorial, 2003. p. 153.

23 GARAPON; GROS; PECH, 2002, p. 124.

24 Ibid., p. 125.

25 Ibid., p. 125-126.

26 Ibid., p. 126 e segs.

27 Ibid., p. 127.

28 Ibid., p. 128.

29 Ibid., p. 129.

Artigo recebido em: 04/11/2010

Aprovado para publicação em: 18/11/2010 